\title{
The face of Earth 12, 26, and 44 million years from now
}

The oceanic spreading record seen today has been extrapolated to predict the future pattern of tectonic plates. This extrapolation suggests that the Pacific Ocean will have disappeared completely about 50 million years after the present. Because Pangea began to disperse 180 million years before the present, the breakup and subsequent aggregation of supercontinents may take a total period of 230 million years.

\section{Introduction}

Traditionally, the geosciences have been preoccupied with the past of our planet ("The present is the key to the past," Lyell, 1830), and only the prediction of geologic hazards in the very near future (say, less than 100 years) has gained some attention (Smith, 1985). However, anticipating the displacement of the Earth's surface plates may add a new dimension to geological thinking: consider a half space that has a time scale starting today and extending far into the future (millions of years). The prediction of future plate motions may widen our knowledge of Earth's evolution, and it forms a challenging academic problem.

Geologists have pieced together a picture that suggests that the process of breakup, dispersal, and renewed aggregation of supercontinents is one of the key characteristics of plate tectonic evolution on Earth. This process of breakup and formation of supercontinents is supposed to occur in a cyclic fashion that was first recognized by Wilson (1966). Pangea, the youngest supercontinent, broke up at 180 $\mathrm{Ma}$ and is still dispersing. The oceanic spreading pattern provides a detailed record of Pangea's dispersal. The past spreading record has been extrapolated here in order to predict how the current Wilson cycle will near its completion. Essentially, this exercise shows that "the past is the key to the future," if major catastrophic events are excluded.

\section{Construction method}

The future displacement of plate boundaries and continents has been constructed on three different globes for three arbitrary increments of time $(12,26$, and 44 m.y. A.P. (after present)). Commercially available styrofoam spheres of $10-\mathrm{cm}$ radius were each transformed into a globe by drawing with a black permanent line marker a geographic grid of $20^{\circ}$ spacing on the spherical surface (see Weijermars, 1986a). Similar spheres have been used previously to reconstruct past plate motions since the dispersal of Pangea (Weijermars, 1989). The geographic grid provides the frame of reference required to transfer the ocean-floor age pattern onto the globe so that it becomes a scale model of the present-day Earth (fig. 1a). The oceanic spreading pattern used in the construction is that compiled by Sclater and others (1980, 1981), which has been simplified here into five major age bands: Neogene (0--20 Ma), Palaeogene (20-65 Ma), Late Cretaceous (65-95 Ma), Early Cretaceous (95-140 Ma), and Middle and Late Jurassic (140-180 Ma). The minor modifications made by Larson and others (1985) to the original map of Sclater and others (1981) have been neglected in the present study in order to maintain full compatibility with my previous construction of Pangea's dispersal (Weijermars, 1989).

Thin mobile copies of the present-day plates, which have the same curvature as the plates on the styrofoam globe (fig. 1b), can be manufactured easily by using transparent drawing paper (Weijermars, 1986a). These transparent plates are refitted on a new global model by shifting apart the modern outlines of the lithospheric plates and leaving gaps along the spreading ridges (fig. 1c). The width of the gaps is controlled by the production rate of oceanic lithosphere. Neat globes of the future Earth can be manufactured by cutting away and redrawing the older age bands of the transparent plates (fig. 1d).

Although the tools used here are extremely simple, the accuracy of this manual construction technique is comparable to that of digitized construction methods (compare Weijermars, 1989). In fact, the uncertainty in Sclater and others' (1981) isochron pattern, poorly defined for some 20 percent of the ocean floor, is more significant than the uncertainty for any of the construction techniques available. Dutch (1985) has outlined how even flat cardboard sheets can be used to construct plate tectonic patterns on low-cost polyhedral approximations to a sphere.

\section{Basic assumptions}

The present constructions of the future configuration of Earth's plates assume that, for the next 50 m.y.:

(1) Any expansion of the Earth's radius will be negligible.

(2) The area of continental lithosphere will remain constant,

(3) Antarctica will remain fixed relative to both the lower manthe and the geographic grid,

(4) Major catastrophies leading to apocalyptic changes in the plate tectonic development of Earth will not occur, and

(5) Production of oceanic lithosphere will occur symmetrically about the oceanic ridges at a mean worldwide rate of $3.5 \mathrm{~km}^{2} / \mathrm{yr}$. The basis of these assumptions will be outlined below, but assumptions 1-3 have been discussed extensively in previous work (Weijermars, 1986a, 1989).

\section{Expansion}

Earth-expansion hypotheses can be divided into two major types: fast and slow. Fast Earth-expansion hypotheses suggest that the Earth was a small planet and had a constant radius of $5.100 \mathrm{~km}$ (Owen, 1983 ) or $4,000 \mathrm{~km}$ (Carey, 1976; King, 1983) for many billion years, until at about $180 \mathrm{Ma}$ when it suddenly started to expand to 

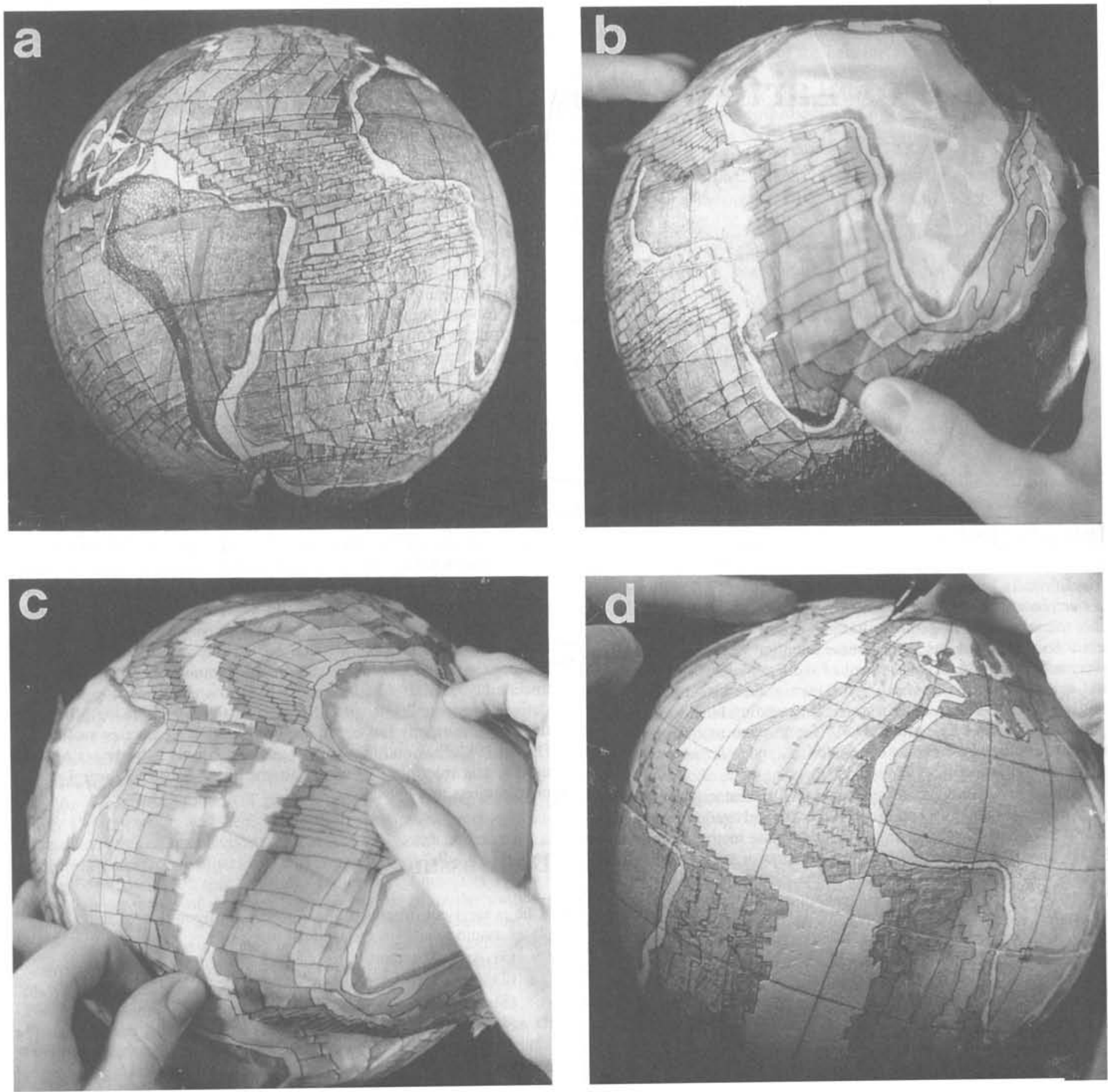

Figure 1.-Synoptic series of photographs illustrating the method for constructing the future evolution of tectonic plates. a, Globe showing the present-day spreading pattern. b, Preparation of transparent replicas of the lithospheric plates. c and d, The African and South American plates are refitted and shifted apart on a new globe in order to outline their position for 26 m.y. A.P. 
its present radius of $6.370 \mathrm{~km}$. These hypotheses assume that gaps were torn in an initially continuous shell of continental crust as the Earth expanded and that these gaps were filled in by all oceanic lithosphere younger than about $180 \mathrm{Ma}$. All fast Earth-expansion hypotheses can be rejected on the basis of geological, geophysical, and cosmological arguments (see Weijermars, 1986a, and references therein).

Slow Earth-expansion hypotheses suggest that the Earth has expanded ever since its formation at about $4.8 \mathrm{Ga}$. Proposed expansion rates vary with the particular hypothesis. All slow Earth-expansion hypotheses also can be discarded on physical grounds (Weijermars. 1986a) except for one. The possibility of slow radial expansion of the Earth as a result of the cooling of the Earth's liquid outer core is difficult to exclude. Nonetheless, even if slow Earth expansion were occurring, the Earth's radius might grow only $26 \mathrm{~km}$ in the next 50 m.y. (compare Weijermars, 1986a). This could add only some 1 percent to the area of the ocean floor if all the surface expansion were confined to the oceans. It, therefore, seems reasonable to neglect any Earth expansion in this study.

\section{Continental growth}

The mode and rate of continental growth probably have varied in the past. However, even if one adopts estimates of extremely fast net growth rates on the order of $1 \mathrm{~km}^{3} / \mathrm{yr}$ (Reymer and Schubert, 1986), this may add only some $\left(50 \times 10^{6} \mathrm{~km}^{3} / 50 \mathrm{~km}=\right) 10^{6} \mathrm{~km}^{2}$ to the continental area in the next $50 \mathrm{~m} . \mathrm{y}$. This is less than 0.01 percent of the modern surface area of the Earth and may, therefore, be neglected in the construction of future plate tectonic models. Similarly, I assume that crustal shortening and extension by local tectonic activity are unlikely to cause any significant change in continental area.

\section{Geographic grid}

The geographic grid should be fixed to the Earth's rotation axis in order to have paleoclimatic significance at any given time. The rotation axis moves relative to the mantle, and so do the surface plates; their relative positions can be fixed as follows. Because the Earth's magnetic dipole field is assumed to be aligned with the Earth's rotation axis, the absolute motion path of the rotation axis is similar to that of the magnetic dipole. This assumes that secular variations of the magnetic pole are neglected by averaging the magnetic track over time, so that the magnetic pole remains close to the instantaneous rotation axis.

The absolute motion of the paleomagnetic pole can be determined by using a hot-spot reference frame. The magnetic pole was $10^{\circ}$ from the present pole at $100 \mathrm{Ma}$ and has spiraled slowly into its present position (Andrews, 1985). This suggests that it is unlikely to be offset more than $10^{\circ}$ from its present position in the next 50 m.y. Because the Antarctic plate seems to be nearly stationary with respect to the mantle (Minster and Jordan, 1978), the assumption is that the geographic pole will remain stable with respect to Antarctica in the plate constructions for the next $50 \mathrm{~m} . \mathrm{y}$.

\section{Catastrophies}

Catastrophic events may interrupt the gradual evolution of any natural system. Obviously, predictions of future plate motions on Earth become invalid if either the Earth suddenly disappears or plate tectonic motion stops before the time for which the predictions are intended. Unexpected changes may come from the Earth's interior, its surface, or outer space.

The interior of the Earth evolves smoothly by chemical differentiation, radiogenic heating, and convective cooling. No indication, whatsoever. exists that any of these three mechanisms will change or stop within the next 50 m.y., which is only a short timespan if compared to the 4.8 b.y. of Earth's history. Accordingly, the evolution of Earth's interior is considered incapable of causing an unexpected change in the evolution of tectonic plates at its surface.

Although an all-out nuclear war among terrestrials probably would destroy the biosphere to a considerable extend (however, see Weijermars. 1986b), tectonic evolution probably would not be affected in any fashion. Another possibility is that extraterrestrial intelligence would have the power to destroy Earth and some motive to realize it. This factor has been discussed at length in science fiction literature. Although this is a possibility - and perhaps a very likely one, as the estimated number of planets in our galaxy having advanced technocratic life is $10^{6}$ (Newman and Sagan, 1981)-I assume that it will not occur.

The remaining cause of a possible catastrophy on Earth is a giant cometary impact. Major impact structures are known from continental areas (McLaren, 1983; Grieve and others, 1985), and large impacts (by bodies of $100-1,000 \mathrm{~km}$ in diameter) have been invokec in order to explain the separation of the Moon from the Earth at about $4 \mathrm{Ga}$ (Ringwood, 1986). A giant impact, if sufficiently large, probably could melt and destroy the Earth entirely, but here the assumption is that such a collision will not occur in the next $50 \mathrm{~m} . \mathrm{y}$.

\section{Production rate}

Current estimates of the production rate of oceanic lithosphere are listed in table 1. Estimates that have been made for the last 10 to 20 m.y. must be considered the most accurate because estimates of the production rate that include older lithosphere tend to be too low, as : result of the loss of old lithosphere from the record after subduction. A production rate of $3.5 \mathrm{~km}^{2} / \mathrm{yr}$ seems to be a good approximation for modern times and has been used as a characteristic production rate in my constructions of the future of the globe.

\section{Table 1.-Estimates of production rates of oceanic lithosphere}

\begin{tabular}{|c|c|c|}
\hline $\begin{array}{l}\text { Rate } \\
\left(\mathrm{km}^{2} / \mathrm{yr}\right)\end{array}$ & $\begin{array}{l}\text { Averaged over } \\
\text { period of the } \\
\text { last }(m, y)\end{array}$ & Reference \\
\hline $\begin{array}{l}2.65 \\
2.9 \\
2.99 \\
3 \\
3.1 \\
3.45 \\
3.5\end{array}$ & $\begin{array}{c}180 \\
140 \\
180 \\
180 \\
5-10 \\
20 \\
20\end{array}$ & $\begin{array}{l}\text { Deffeyes }(1970) \\
\text { Weijermars }(1989) \\
\text { Parsons }(1981) \\
\text { Chase }(1972) \\
\text { Garfunkel }(1975) \\
\text { Sclater and others }(1980) \\
\text { Weijermars (1989) }\end{array}$ \\
\hline
\end{tabular}

${ }^{1}$ The period indicated is estimated if not properly acknowledged in the original paper

\section{Results}

Figure 2 illustrates the spreading pattern of the present-day Earth in oblique and equatorial orthographic projections. These projections have been drawn from photographs of the globe shown in figure la. Figures 3 to 5 illustrate the spreading patterns of the future Earth at 12,26 , and 44 m.y. A.P., respectively, in similar projections drafter from unpublished photographs of the globes constructed

The area of the new lithosphere created along the oceanic ridge: was measured on the globes and used to determine the corresponding age of the future Earth (table 2). In the constructions. all continental margins that are passive today remain passive throughout the next $4-$ m.y. This is because no major collision of continents will occur within this timespan. Similarly, the ending of subduction zones is unlikely to occur because cold and heavy oceanic lithosphere will remain available to sink away under active plate boundaries. 

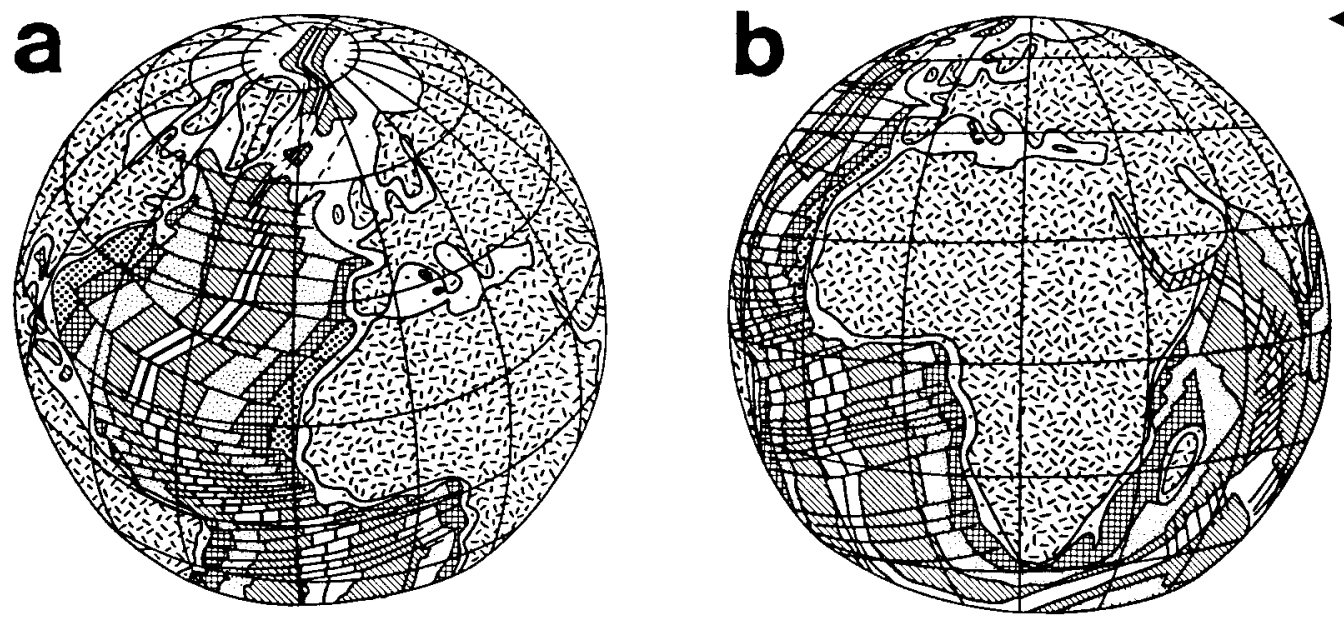

4 Figure 2.-Global views of the oceanic spreading pattern on the modern Earth in oblique (a, c-e) and equatorial (b, f) orthographic projections. Compiled after the data of Sclater and others (1981). Final drafts of figures 2-5 were made by Christina Wernström of Uppsala University.
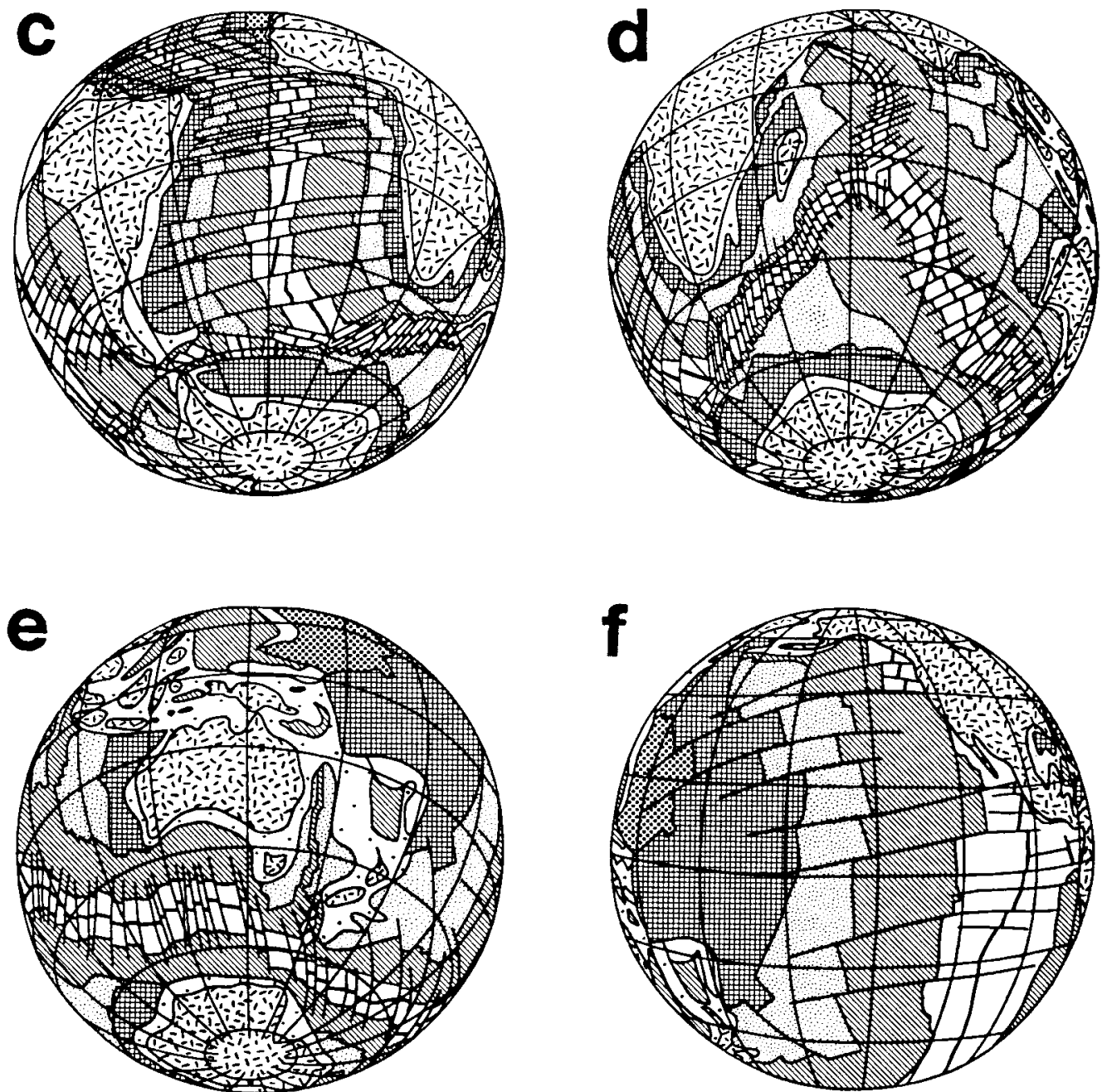

CONTINENTAL CRUST

$\because$ Shelf

E-i, Continent
OCEANIC CRUST

Spreading ridge

Neogene
$(0-20 \mathrm{Ma})$
Palaeogene
(20-65 Ma)

Late Cretaceous (65-95 Ma)
Early Cretaceous (95-140 Ma)

Middle and Late Jurassic

$(140-180 \mathrm{Ma})$ 

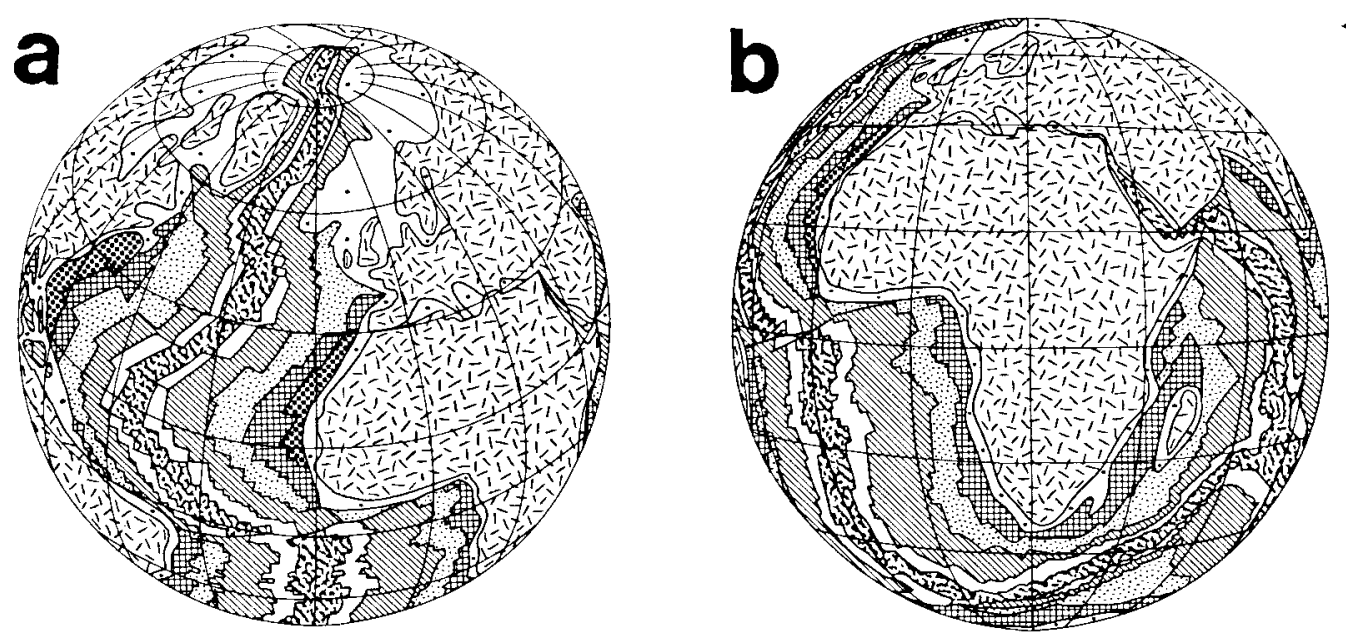

4 Figure 3.-Spreading pattern for the Earth at $12 \mathrm{~m} . y$. A.P. The muddled band outlines the spreading centers and the oceanic lithosphere that will be produced in the next $12 \mathrm{~m} . y$. Note that Australia slides past the Indonesian island arc and consumes the Phillipine Basin (e).
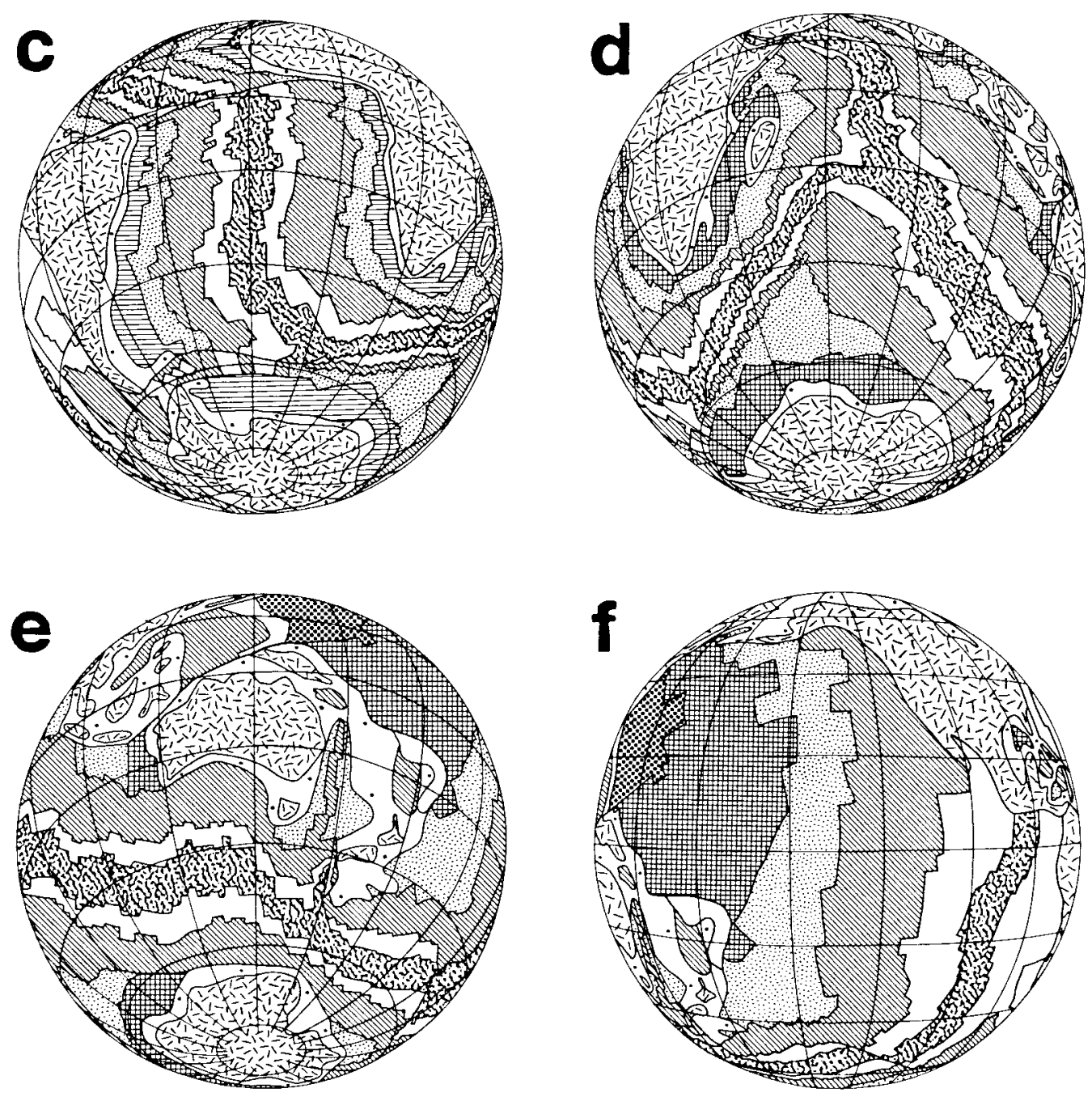

CONTINENTAL CRUST

$\because$ Shelf

过 Continent
OCEANIC CRUST

FD缽 Future

(12-0 m.y. A.P.) Neogene
Palaeogene (20-65 Ma) Late Cretaceous $\%$ Middle and Late Jurassic (65-95 Ma)
Early Cretaceous

(95-140 Ma)

(140-180 Ma) 

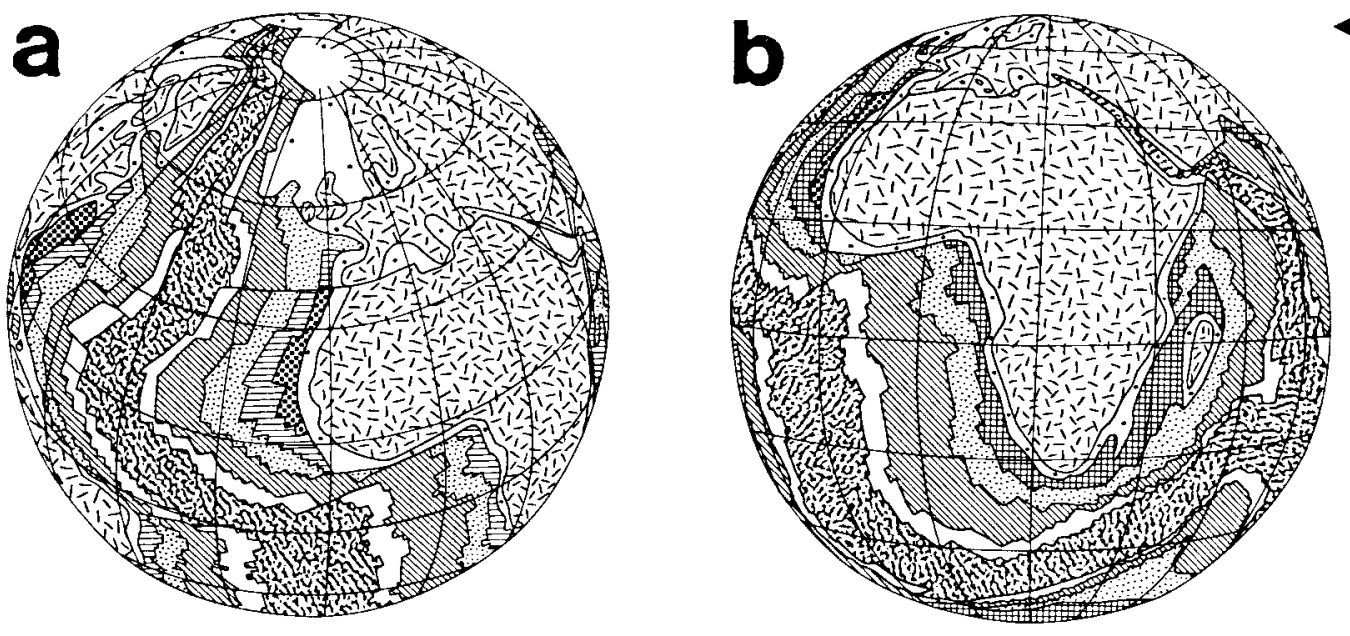
4 Figure 4. - The Earth's spreading pattern constructed for 26 m.y. from today.
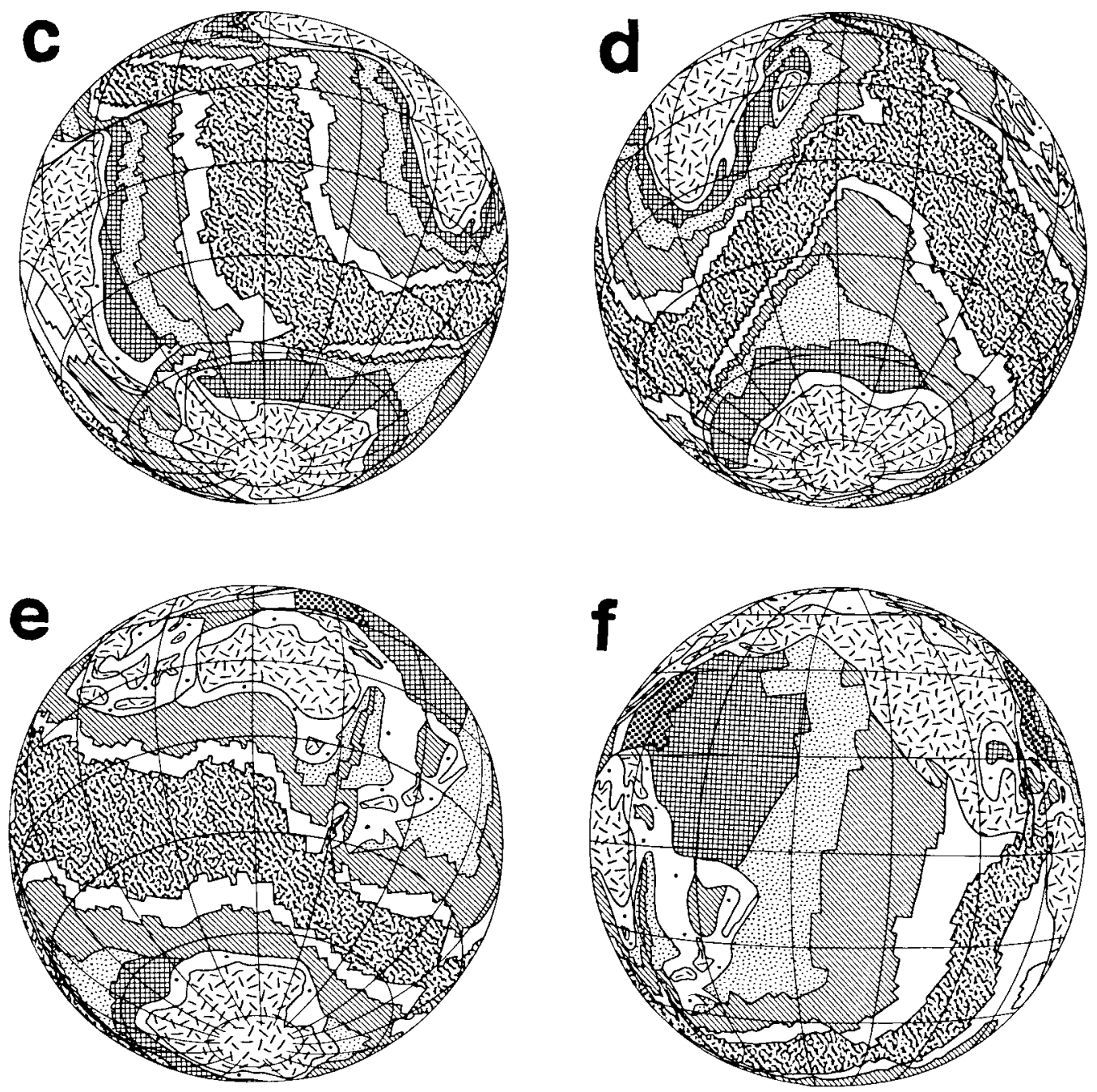

\begin{tabular}{|c|c|c|c|}
\hline CONT & CRUS & OCEAN & VIC CRUST \\
\hline$\because$ & Shelf & 98: & $\begin{array}{l}\text { Future } \\
(26-0 \text { m.y. A.P.) }\end{array}$ \\
\hline 这 & Continent & & $\begin{array}{l}\text { Neogene } \\
\text { (0-20 Ma) }\end{array}$ \\
\hline
\end{tabular}

Paleaogene (20-65 Ma) Late Cretaceous $\%$ Middle and Late Jurassic (65-95 Ma) 

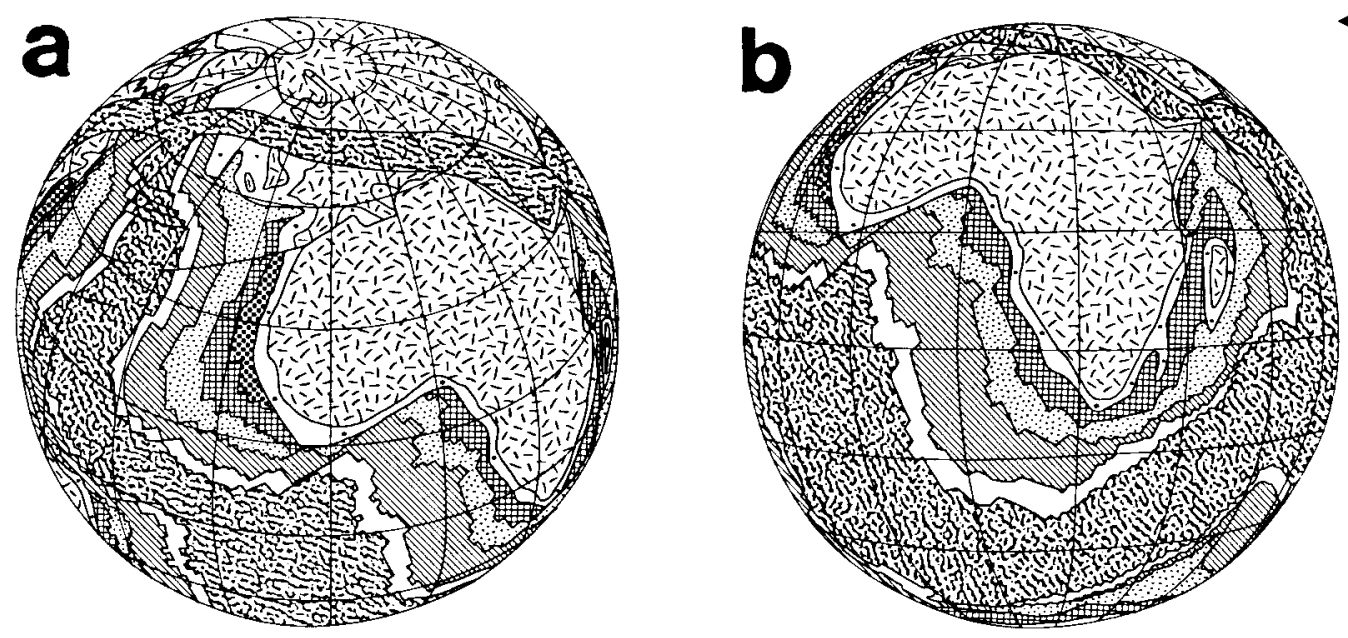

$4 \quad$ Figure 5.-Oceanic isochron pattern near the closure of the Pacific Ocean (f) at 44 m.y. A.P.
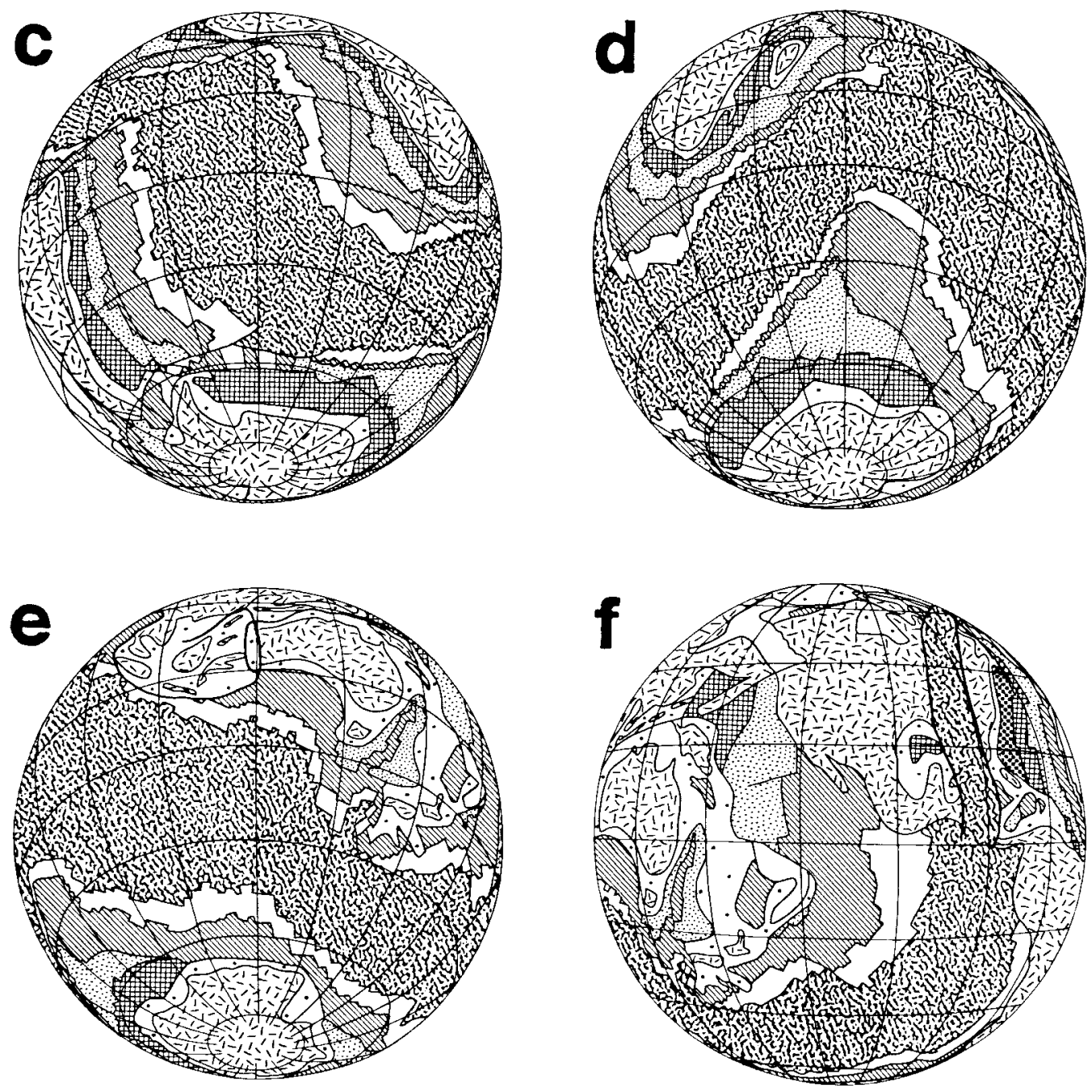

\begin{tabular}{|c|c|c|}
\hline con & NENTAL CRUS & OCEANIC CRUST \\
\hline$\because$ & Shelf & $\begin{array}{l}\text { Future } \\
\text { (44-0 m.y. A.P }\end{array}$ \\
\hline 迆 & Continent & $\begin{array}{l}\text { Neogene } \\
(0-20 \mathrm{Ma})\end{array}$ \\
\hline
\end{tabular}

Palaeogene (20-65 Ma) Late Cretaceous (65-95 Ma)
Early Cretaceous

(95-140 Ma)

Middle and Late Jurassic

(140-180 Ma) 
Table 2.-Conversion of spreading patterns to future ages on the model globes of figures 3-5, assuming a constant production rate of $3.5 \mathrm{~km}^{2} / \mathrm{yr}$

\begin{tabular}{|c|c|c|c|c|}
\hline \multicolumn{2}{|c|}{$\begin{array}{c}\text { Area of lithosphere } \\
\text { produced }\end{array}$} & \multicolumn{2}{|c|}{$\begin{array}{c}\text { Assumed production } \\
\text { rate }\end{array}$} & \multirow{2}{*}{$\begin{array}{l}\mathrm{Age} \\
\mathrm{AP} \\
\mathrm{AP}\end{array}$} \\
\hline $\begin{array}{l}\text { Model } \\
\left(\mathrm{cm}^{2}\right)\end{array}$ & $\begin{array}{c}\text { Earth } \\
\left(10^{6} \mathrm{~km}^{2}\right)\end{array}$ & $\begin{array}{l}\text { Earth } \\
\left(\mathrm{km}^{2} / \mathrm{yr}\right)\end{array}$ & $\begin{array}{l}\text { Model } \\
\left(\mathrm{cm}^{2} / \mathrm{m}, \mathrm{y}\right)\end{array}$ & \\
\hline 103 & 41.7 & 3.5 & 8.6 & 12 \\
\hline 224 & 90.9 & 3.5 & 8.6 & 26 \\
\hline 383 & 155.4 & 3.5 & 8.6 & 44 \\
\hline
\end{tabular}

$1 \mathrm{~cm}^{2}$ of area on the model globes corresponds to $(637)^{2} \mathrm{~km}^{2}$ of the real Earth.

${ }^{2}$ Million years after present. The ages indicated would be 14.30 , and 52 m.y. A.P. if a slower production rate of $3 \mathrm{~km}^{2} / \mathrm{yr}$ were assumed.

Some of the major features seen in the constructions are the sliding of Australia past the Indonesian island arc into the Phillipine Sea (fig. 3e) and the subsequent squeezing of Japan between the People's Republic of China and Australia at 44 m.y. A.P. (fig. 5f). Figures $2 \mathrm{f}, 3 \mathrm{f}, 4 \mathrm{f}$, and $5 \mathrm{f}$ illustrate the progressive closure of the Pacific Ocean due to continued growth of the passive-margin oceans at the expense of the active-margin Pacific.

Whilst passive and active margins will remain approximately similar to those seen today, some spreading ridges may be expected to propagate slowly across continents. At present, five active spreading ridges hit continental crust, that is, the Nansen Ridge terminating against the Siberian shelf (Srivastava and Tapscott, 1986); the Juan de Fuca Ridge in the east Pacific; the Cocos Ridge and Chile Rise, branches of the East Pacific Rise (McCrory, 1989; Hey and others, 1986; Cande and others, 1987; Herron and others, 1981); the Macquarie Ridge near New Zealand (Kamp, 1986); and the Red Sea rift. Of these ridges, the Nansen and Macquarie Ridges both have been spreading adjacent to continental crust since the Tertiary without any significant propagation into the adjacent continental crust. These ridges, therefore, are not expected to propagate any further in the next $50 \mathrm{~m} . \mathrm{y}$. The Juan de Fuca Ridge will be subducted beneath North America's west coast within the next $12 \mathrm{~m}$.y. (see fig. $3 \mathrm{f}$ ). Although the Cocos Ridge and Chile Rise still are very active today, these branches of the East Pacific Rise have been neglected for convenience in the present study.

The Red Sea rift and the East Pacific Rise, the two major spreading centers remaining, are expected to rift further into the continental crusts of West Europe and North America, respectively, as is portrayed in figures $4 \mathrm{~b}$ and $\mathrm{f}$ and $5 \mathrm{~b}$ and $\mathrm{f}$. These rifts are expected to propagate into the continents along zones where the continental lithosphere already is known to be relatively thin. These locations have been inferred from seismic estimates of the lithospheric thickness in West Europe (Suhadolc and Panza, 1988) and in North America (Allenby and Schnetzler, 1983).

\section{Conclusions}

The future world does not yet exist and perhaps never will. However, if the Earth may have its way, the completion of the current Wilson cycle will be heralded by the invasian of Australian kangaroos into Japan some 45 m.y. from now. We live such a short time that it seems useless to bother about the political consequences of Australia indenting China, the USA splitting apart, or a gap widening between the countries of the European Community. Nonetheless, the maps of future plate boundaries illustrated here may provide some mental support to those who realize that the present geographic division of our planet is only temporary and transient and that this geographic division should not inhibit the development of peaceful ties between worlds now still apart.

\section{References}

Allenby, R.J., and Schnetzler, C.C., 1983, United States crustal thickness: Tectonophysics, v. 93, p. 13-31.

Andrews, J.A., 1985, True polar wander: An analysis of Cenozoic and Mesozoic palaeomagnetic poles: Journal of Geophysical Research, v. 90, p. $7737-7750$.

Cande, S.C., Leslie, R.B., Parra, J.C., and Hobart, M. . 1987, Interaction of the Chile ridge and the Chile trench: Geophysical and geothermal evidence: Journal of Geophysical Research, v. 92, p. 495-520.

Carey, S.W., 1976, The expanding Earth: Amsterdam. Elsevier, 488 p.

Chase, C.G., 1972, The N plate problem of plate tectonics: Geophysical Journal of the Royal Astronomical Society, v. 29, p. 117-122.

Deffeyes, K.S., 1970. The axial valley, a steady-state feature of the terrain. in Johnson, Helgi, and Smith, B.L., eds., The megatectonics of continents and oceans: New Brunswick, New Jersey, USA, Rutgers University Press, p. 194-222.

Dutch, S.I., 1985, Pseudoglobes for the earth-science classroom: Journal of Geological Education, v. 33, p. 128-131.

Garfunkel, Z., 1975, Growth, shrinking and long-term evolution of plates and their implications for the flow pattern in the mantle: Journal of Geophysical Research, v, 80, p. 4425-4432.

Grieve, R.A.F., Sharpton, V.L., Goodacre, A.K., and Garvin, J.B., 1985. A perspective on the evidence for periodic cometary impacts on Earth: Earth and Planetary Science Letters, v. 76, p. 1-9.

Herron, E.M., Cande, S.C., and Hall, B.R., 1981, An active spreading center collides with a subduction zone: A geophysical survey of the Chile margin triple junction: Geological Society of America Memoir 154, p. $683-701$.

Hey, R.N., Kleinrock, M.C., Miller, S.P., Atwater, T.M., and Searle, R.C., 1986, Sea Beam/deep-tow investigation of an active oceanic propagating rift system, Galapagos 95.5 W: Journal of Geophysical Research, v. 91, p. 3369-3393.

Kamp, P.J.J., 1986, The mid-Cenozoic Challenger rift system of western New Zealand and its implications for the age of Alpine fault inception: Geological Society of America Bulletin, v. 97, p. 255-281.

King, L.C., 1983, Wandering continents and spreading sea floors on an expanding Earth: New York, John Wiley, 232 p.

Larson, R.L., Pitman, W.C., III, Golovchenko, X., Cande, S.C., Dewey, J.F., Haxby, W.F., and LaBrecque, J.L., 1985, The bedrock geology of the world: New York, W.H. Freeman, 1 sheet.

Lyell, Charles, 1830, Principles of geology (1st edition): London, John Murray, v. 1.

McCrory, P.A., 1989, Late Neogene geohistory analysis of the Humboldt Basin and its relationship to convergence of the Juan de Fuca plate: Journal of Geophysical Research, v. 94, p. 3126-3138.

McLaren, Digby, 1983, Impacts that changed the course of evolution: New Scientist, v. 100 , no. 1385 , November 24 , p. $588-595$.

Minster, J.B., and Jordan, T.H., 1978, Present-day plate motions: Journal of Geophysical Research, v. 83, p. 5331-5354.

Newman, W.I., and Sagan, C., 1981, Galactic civilizations: Population dynamics and interstellar diffusion: Icarus, v. 46, p. 293-327.

Owen, H.G., 1983, Atlas of continental displacement, 200 million years to present: Cambridge, UK, Cambridge University Press, $159 \mathrm{p}$.

Parsons, B., 1981, The rates of plate consumption and creation: Geophysical Journal of the Royal Astronomical Society, v. 67, p. 437-448

Reymer, A., and Schubert, G., 1986, Rapid growth of some major segments of continental crust: Geology, v. 14, p. 299-302.

Ringwood, A.E., 1986, Terrestrial origin of the Moon: Nature, v. 322, p. 323-328.

Sclater, J.G., Jaupart, C., and Galson, D., 1980, The heat flow through oceanic and continental crust and the heat loss of the Earth: Reviews of Geophysics and Space Physics, v. 18, p. 269-311.

Sclater, J.G., Parsons, B., and Jaupart, C., 1981, Oceans and continents: Similarities and differences in the mechanisms of heat-loss: Journal of Geophysical Research, v. 86, p. 11535-11552. 
Smith, J.V., 1985, Protection of the human race against natural hazards (asteroids, comets, volcanoes, earthquakes): Geology, v. 13, p. 675-678.

Srivastava, S.P., and Tapscott, C.R., 1986, Plate kinematics of the North Atlantic, in Vogt, P.R., and Tucholke, B.E., eds., The western North Atlantic region, v. M of The geology of North America: Boulder, Colorado, USA, Geological Society of America, p. 379-404.

Suhadolc, P., and Panza, G.F., 1988, The European-African collision and its effects on the lithosphere-asthenosphere system: Tectonophysics, v. 146. p. 59-66.

Weijermars, Ruud, 1986a, Slow but not fast global expansion may explain the surface dichotomy of Earth: Physics of the Earth and Planetary Interiors, v. 43 , p. $67-89$.

1986b, Evolution on Earth may tell us what ETI look like: Geology Today, v. 2, p. 89-91.

1989. Global tectonics since the breakup of Pangea 180 million years ago: Evolution maps and lithospheric budget: Earth-Science Reviews, v. 26. p. $113-162$.

Wilson, J.T., 1966, Did the Atlantic close and then reopen?: Nature, v. 211, p. $276-681$

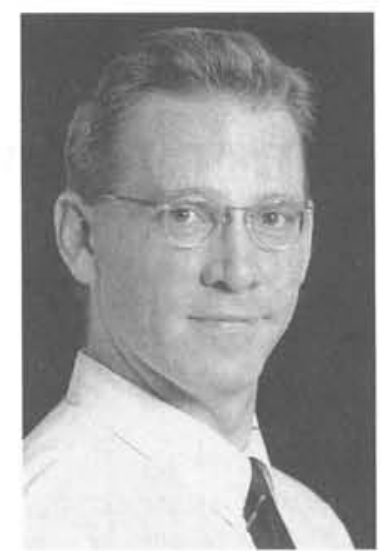

Dr. $R$. Weijermars is a Research Scientist in structural geology and geodynamics at Uppsala University, Sweden. He previously studied and taught field geology at Amsterdam University in The Netherlands. His doctorate program at the Hans Ramberg Tectonic Laboratory at Uppsala focused on the visualization and scaling of deformation patterns in a possible model of mantle convection. Plate reconstructions subsequently captured his interest because they constrain changes in the boundary conditions at the mantle's surface. 